ISSN: 2302-8556

E-Jurnal Akuntansi Universitas Udayana

Vol.25.2.November (2018): 1481-1505

DOI: https://doi.org/10.24843/EJA.2018.v25.i02.p25

\title{
Pengaruh Kompensasi Eksekutif, Koneksi Politik, dan Capital Intensity pada Tax Avoidance
}

\section{A.A. Ayu Nur Cintya Apsari ${ }^{1}$ Ni Luh Supadmi}

${ }^{1}$ Fakultas Ekonomi dan Bisnis Universitas Udayana (Unud), Bali, Indonesia email: apsaricintya@gmail.com/ Telp: +6281237419746

${ }^{2}$ Fakultas Ekonomi dan Bisnis Universitas Udayana (Unud), Bali, Indonesia

\begin{abstract}
ABSTRAK
Penelitian ini bertujuan untuk mengetahui pengaruh kompensasi eksekutif, koneksi politik, dan capital intensity pada tax avoidance.Penelitian ini dilaksanakan pada perusahaan property, real estate, dan konstruksi bangunan yang terdaftar di Bursa Efek Indonesia tahun 2014-2016. Jumlah sampel yang digunakan dalam penelitian ini sebanyak 12perusahaan dengan jumlah observasi 36 . Metode penentuan sampel penelitian ini adalah non-probability sampling dengan teknikpurposive sampling. Teknik analisis data dilakukan dengan menggunakan teknik analisis regresi linear berganda. Hasil penelitian menunjukkan bahwa kompensasi eksekutif berpengaruhnegatifdan signifikan pada tax avoidance. Penelitian ini juga menemukan bahwa koneksi politik dan capital intensity berpengaruh negatif dan tidak signifikan pada tax avoidance.
\end{abstract}

Kata kunci: Kompensasi Eksekutif, Koneksi Politik, Capital Intensity, Tax Avoidance

\begin{abstract}
This study aims to determine the effect of executive compensation, political connections, and capital intensity on tax avoidance. This research was carried out on property, real estate, and building construction companies listed on the Indonesia Stock Exchange in 2014-2016. The number of samples used in this study were 12 companies with the number of observations 36. The method of determining the sample of this study was nonprobability sampling with purposive sampling technique. Data analysis techniques were carried out using multiple linear regression analysis techniques. The results showed that executive compensation had a negative and significant effect on tax avoidance. This study also found that political connections and capital intensity have a negative and not significant effect on tax avoidance.
\end{abstract}

Keyword: Executive Compensation, Political Connections, Capital Intensity, Tax Avoidance 


\section{PENDAHULUAN}

Indonesia merupakan negara berkembang yang hingga kini terus melakukan pembangunan nasional untuk mensejahterakan rakyatnya. Terdapat dua sumber dana untuk melakukan pembangunan nasional, yaitu sumber pendanaan yang berasal dari pajak dan non pajak. Pajak merupakan sumber penerimaan utama sekaligus menjadi penopang pembiayaan pembangunan bersumber dari dalam negeri yang paling penting.Pajak penghasilan berdasarkan peraturan undang-undang perpajakan yang berlaku adalah salah satu sumber pajak negara yang diperoleh dari penghasilan wajib pajak sesuai dengan pekerjaan dan kegiatan usaha yang dilakukan (Utari dan Supadmi, 2017).

Pajak dimaknai sebagai sesuatu yang merugikan dan memberatkan wajib pajak karena pajak dapat menurunkan kemampuan daya beli masyarakat (Mulyani dkk, 2014).Perusahaan merasalaba perusahaanberkurang disebabkan oleh beban pajak yang harus dibayarkan. Perusahaan yang tidak membayar kewajiban pajaknya akan diberikan sanksi oleh pemerintah.Sistem pemungutan pajak yang digunakan di Indonesiaadalah self assessment system.Penyelewengan dan pelanggaran pajak paling rentan terjadi padaself assessment system.

Penyelewengan dan pelanggaran pajak adalah salah satu bentuk penghindaran pajak (Mulyani dkk, 2014).Perlawanan pajak dibedakan menjadi perlawanan aktif danpasif (Sumarsan, 2010).Perlawanan secara aktif dibagi menjadi dua yaitu penggelapan pajak (tax evasion) dan penghindaran pajak (tax avoidance). Tax 
evasion merupakan upaya-upaya yang dilakukan wajib pajak untuk mengurangi utang pajaknya secara illegal.Tax avoidanceadalah upaya yang dilakukan wajib pajak untuk menghindari pajak secara legal dan aman.

Fenomena tentang penghindaran pajak yang terjadi di Indonesia dapat ditemukan pada kasus Google.Google mendirikan induk usaha di Singapura yang terkenal sebagai negara dengan tarif pajaknya yang rendah untuk menangani bisnisnya di ASIA termasuk Indonesia.Google menyatakan tidak memiliki Bentuk Usaha Tetap (BUT) di Indonesia karena faktanya seluruh kontrak dijalankan tanpa melalui kantor perwakilan di negara ini, seluruh kontrak yang dilakukan antara Google dengan konsumen di Indonesia berlangsung secara online. BUT merupakan satu syarat atau ambang batas negara sumber penghasilan bisa memungut pajak.Tanpa BUT, tax treaty tidak berhak memajaki penghasilannya yang didapat dari iklan secara online(Arianti, 2016).

Berdasarkan data yang diperoleh dari www.pajak.go.id, pada tahun 2014 2016 efektivitas pemungutan pajak terus mengalami penurunan yang disebabkan adanya pemungutan pajak yang banyak sehingga memiliki beberapa masalah.Efektivitas pemungutan pajak disajikan pada Tabel 1berikut. 
Tabel 1.

Efektivitas Pemungutan Pajak di Indonesia

\begin{tabular}{cccc}
\hline Tahun & $\begin{array}{c}\text { Target } \\
(\mathbf{R p})\end{array}$ & $\begin{array}{c}\text { Realisasi } \\
(\mathbf{R p})\end{array}$ & $\begin{array}{c}\text { Efektifitas } \\
\text { Pemungutan Pajak } \\
\text { (persen) }\end{array}$ \\
\hline 2014 & 1.072 Triliun & 981 Triliun & 91,51 \\
2015 & 1.294 Triliun & 1.060 Triliun & 81,91 \\
2016 & 1.355 Triliun & 1.105 Triliun & 81,54 \\
\hline
\end{tabular}

Sumber: www.pajak.go.id, 2018.

Tabel 1menunjukkan bahwa target pemungutan pajak tahun 2014 sebesar 1.072 Triliun, sedangkan realisasi pemungutan pajaknya adalah sebesar 981 Triliun, sehingga efektifitas pemungutan pajak tahun 2014 adalah 91,51 persen. Target pemungutan pajak tahun 2015 sebesar 1.294 Triliun, sedangkan realisasi pemungutan pajaknya adalah sebesar 1.060 Triliun, sehingga efektifitas pemungutan pajak tahun 2015 adalah 81,91 persen. Target pemungutan pajak tahun 2016 sebesar 1.355 Triliun, sedangkan realisasi pemungutan pajaknya adalah sebesar 1.105 Triliun, sehingga efektifitas pemungutan pajak tahun 2016 adalah 81,54 persen. Tabel 1.1 menunjukan bahwa target penerimaan pajak dan realisasinya mengalami kenaikan dari tahun 2014-2016, sedangkan efektifitas pemungutan pajak mengalami penurunan. Pengunaan data pada tahun 2014-2016 karena persentase kenaikan realisasi pemungutan pajak tidak seimbang dengan persentase kenaikan target pemungutan pajak.

Salah satu penyebab tidak tercapainya target pajak disebabkan oleh adanya kompensasi eksekutif. Hasil kebijakan perusahaan salah satunya ialah keputusan penghindaran pajak. Individu yang terlibat dalam pembuatan keputusan pajak di suatu 
ISSN: 2302-8556

E-Jurnal Akuntansi Universitas Udayana

Vol.25.2.November (2018): 1481-1505

perusahaan secara langsung, adalah direktur pajak dan konsultan pajak perusahaan.Eksekutif perusahaan mempengaruhi segala keputusan, termasuk keputusan penghindaran pajak perusahaan. Eksekutif akan bersedia membuat kebijakan penghindaran pajak apabila mendapatkan keuntungan dari kebijakan yang telah dilakukan. Upaya terbaik dalam pelaksanaan efisiensi pajak perusahaan adalah memberikan kompensasi tinggi kepada eksekutif.

Penelitian terdahulu mengenai kompensasi eksekutif pada tax avoidance terdapat ketidak konsistenan hasil yang diperoleh. Penelitian yang dilakukan Desai dan Dharmapala (2006), Minnick dan Noga (2010), Rego dan Wilson (2012), serta Hanafi dan Hartono (2014) menjelaskan kompensasi eksekutif berpengaruh positif pada penghindaran pajak. Penelitian tersebut tidak didukung oleh penelitian Irawan dan Farahmita (2012), Puspita dan Harto (2014), Dewi dan Maria (2015) serta Setyowati (2016) menyatakan kompensasi eksekutif tidak berpengaruh pada penghindaran pajak.

Faktor yang dapat mempengaruhi tax avoidance selain kompensasi eksekutif adalah koneksi politik.Faktor politik memengaruhi keberhasilan bisnis yang dilakukan perusahaan.Leuz dan Gee (2006) menyatakan dalam menyusun strategi bersaing perusahaan harus mampu mencari dan memanfaatkan peluang dan lingkungan bisnis, salah satunya melalui koneksi politik. Purwoto (2011) mengemukakan keterikatan secara politik atau menjalin hubungan dengan pemerintah, maka perusahaan tersebut dapat dikatakan memiliki koneksi poitik. Faccio (2006) mengemukakan perlakuan khusus dari pemerintah motivasi perusahaan 
untuk memilih koneksi politik terutamaperusahaan yang dimiliki langsung oleh pemerintahan.

Penelitian terdahulu mengenai koneksi politik pada tax avoidance terdapat ketidak konsistenan hasil yang diperoleh. Penelitian yang dilakukan Dharma dan Ardiana (2016), serta Lestari dan Asri (2017) yang menghasilkan bukti empiris koneksi politik tidak memiliki pengaruh pada tax avoidance. Penelitian tersebut tidak didukung oleh penelitian Adhikari dkk. (2006), Mulyani dkk.(2013), serta Tehupuring dan Rossa (2016) menemukan koneksi politik berpengaruh negatif pada penghindaran pajak. Penelitian tersebut berbeda dengan penelitian Butje dan Tjondro (2014), Ferdiawan dan Firmansyah (2017), serta Utari dan Supadmi (2017) menyatakan koneksi politik berpengaruh positif pada tax avoidance.

Faktor capital intensity (intensitas modal) juga dapat mempengaruhi pembayaran pajak suatu perusahaan. Capital intensity adalah besarnya investasi aset pada aset tetap perusahaan. Rodiguez dan Arias (2012) menyatakanpemotongan pajak dapat diakibatkan dari depresiasi aktiva tetap perusahaan setiap tahunnya.Biaya penyusutan yang meningkat, menyebabkan pembayaran pajak perusahaan semakin kecil.Capital intensity perusahaan yang tinggi mengakibatkan efektifitas pajak semakin rendah, efektifitas pajak yang rendah dapat diartikan perusahaan melakukan tax avoidance (Wiguna dan Jati, 2017).

Penelitian terdahulu mengenai capital intensity pada tax avoidance terdapat ketidak konsistenan hasil yang diperoleh. Penelitian yang dilakukan oleh Chiou et al.(2012), Ardyansyah (2014), serta Cahyadi dan Lely (2016) menemukan bahwa 
ISSN: 2302-8556

E-Jurnal Akuntansi Universitas Udayana

Vol.25.2.November (2018): 1481-1505

variabel capital intensity tidak memiliki pengaruh pada penghindaran pajak (tax avoidance). Penelitian tersebut berbeda dengan penelitian Surbakti (2012), Dwilopa (2016), serta Dharma dan Naniek (2017) mengemukakan bahwa capital intensity berpengaruh positif pada penghindaran pajak. Penelitian tersebut tidak didukung oleh penelitian Muzakki dan Darsono (2015), Dharma dan Ardiana (2016)capital intensity berpengaruh negatif pada penghindaran pajak.

Rumusan masalah pada penelitian ini adalah 1) Apakah kompensasi eksekutif berpengaruh pada tax avoidance?, 2) Apakah koneksi politik berpengaruh pada tax avoidance?, 3) Apakah capital intensity berpengaruh pada tax avoidance?. Tujuan penelitian ini yaitu untuk memperoleh bukti empiris pengaruh kompensasi eksekutif, koneksi politik, dan capital intensity pada tax avoidance.Manfaat teoritis penelitian, memberikan bukti empiris mengenai teori yang digunakan dalam penelitian adalah teori agensi, mendefinisikan hubungan agen dengan principal, serta theory of planned behavior yang menyatakan bahwa perilaku yang ditimbulkan oleh individu muncul karena adanya niat untuk berperilaku. Secara praktis dapat memberikan masukan pada perusahaan yang diteliti agar kedepannya dapat dijadikan sebagai bahan pertimbangan untuk melakukan praktik penghindaran pajak agar terhindar dari sanksi administrasi perpajakan

Penelitian ini menggunakan teori agensi dan theory of planned behavior. Jensen dan Meckling, (1976) mengemukakan hubungan keagenan sebagai sebuah kontrak yang menyatakan principal meminta kepada agent untuk melakukan jasa tertentu demi kepentingan principal. Prinsipal sebagai pengambil keputusan memiliki 
kekuasaan untuk memberikan perintah kepada agent. Agen berkewajiban untuk mempertanggung jawabkan apa yang telah diamanahkan oleh prinsipal kepadanya.

Theory of Planned Behavior (TPB) menjelaskan bahwa perilaku yang ditimbulkan individu muncul karena adanya niat untuk berperilaku.Ajzen (1991) menyatakan bahwa sikap yang mendorong perilaku (attitude toward behavior) merupakan derajat dimana sesesorang memiliki evaluasi atau penilaian positif atau negatif pada perilaku yang akan ditampilkan. Respon yang diberikan adalah hasil proses evaluasipada keyakinan individu yang mendorong perilaku. Teori ini yang relevan menjelaskan perilaku kepatuhan wajib pajak.

Arnold dan McIntyre (2002) menyatakan bahwa, tax avoidanceialah cara sah yang dilakukan wajib pajak untuk meminimalkan beban pajaknya. Salah satu pengukuran yang dapat membuktikan ada atau tidaknya praktik penghindaran pajak yaitu effective tax rate (ETR) total beban pajak penghasilan dibagi laba sebelum pajak. Hanlon dan Heinztman (2010) menyatakan penghindaran pajak yang berasal dari dampak beda temporer dapat digambarkan melakui pendekatan ETR, serta mampu menggambarkan mengenai perubahan beban pajak kini dan pajak tangguhan.

Kompensasi merupakan balas jasa atau imbalan atas kinerja yang diberikan oleh perusahaan khususnya pada eksekutif. Desai dan Dharmapala (2006), Minnick dan Noga (2010), Rego dan Wilson (2012), serta Hanafi dan Hartono (2014) menjelaskan kompensasi eksekutif berpengaruh positif pada penghindaran pajak. Hipotesis yang dapat dikembangkan berdasarkan uraian tersebut adalah:

$\mathrm{H}_{1}$ : Kompensasi eksekutif berpengaruh positif pada tax avoidance 
ISSN: 2302-8556

E-Jurnal Akuntansi Universitas Udayana

Vol.25.2.November (2018): 1481-1505

Faccio (2006) mengemukakan perusahaan dikatakan mempunyai hubungan politik jika salah satu pimpinan perusahaan atau stockholder merupakan anggota menteri, parlemen, dan orang yang mengetahui kebijakan pemerintah terlebih dahulu (Dharma \& Ardiana, 2016). Kepentingan entitas yang berbeda dapat menimbulkan niat untuk melakukan kepentingan politikseperti yang dijelaskan oleh teori agensi. Lestari dan Asri (2017) mengemukakan pemeriksaan pajak yang rendah menyebabkan perusahaan tidak takut melakukan perencanaan pajak, selain itu jika terjadi krisis ekonomi perusahaan memperoleh hak-hak istimewa. Penelitian yang dilakukan oleh Butje dan Tjondro (2014), Ferdiawan dan Firmansyah (2017), serta Utari dan Supadmi (2017) meyatakan koneksi politik berpengaruh positif pada tax avoidance. Hipotesis yang dapat dikembangkan berdasarkan uraian tersebut adalah:

$\mathrm{H}_{2}$ : Koneksi politik berpengaruh positif pada tax avoidance.

Capital Intensity adalah seberapa besar perusahaan menginvestasikan asetnya dalam bentuk aset tetap dan persediaan. Anthony dan Govindarajan (2009) menyatakan setiap individu akan bertindak untuk kepentingan mereka sendirimenurut teoriagensi. Manajer akan menginvestasikan aset tetapnya dengan memanfaatkan dana yang tidak digunakan perusahaan untuk memperoleh keuntungan berupa penyusutan yang akan mengurangi beban pajak (Darmadi dan Zulaikha, 2013). Richardson dan Lanis (2007), Noor et al. (2010), Surbakti (2012), Dwilopa (2016) serta Dharma dan Naniek (2017) mengemukakan capital intensity berpengaruh positif pada tax avoidance. Hipotesis yang dapat dikembangkan berdasarkan uraian tersebut adalah: 
$\mathrm{H}_{3}$ : Capital intensity berpengaruh positif pada tax avoidance.

\section{METODE PENELITIAN}

Variabel yang diuji pada penelitian ini adalah pengaruh kompensasi eksekutif, koneksi politik, dan capital intensity pada tax avoidance. Desain penelitian ini disajikan pada Gambar 1 berikut.

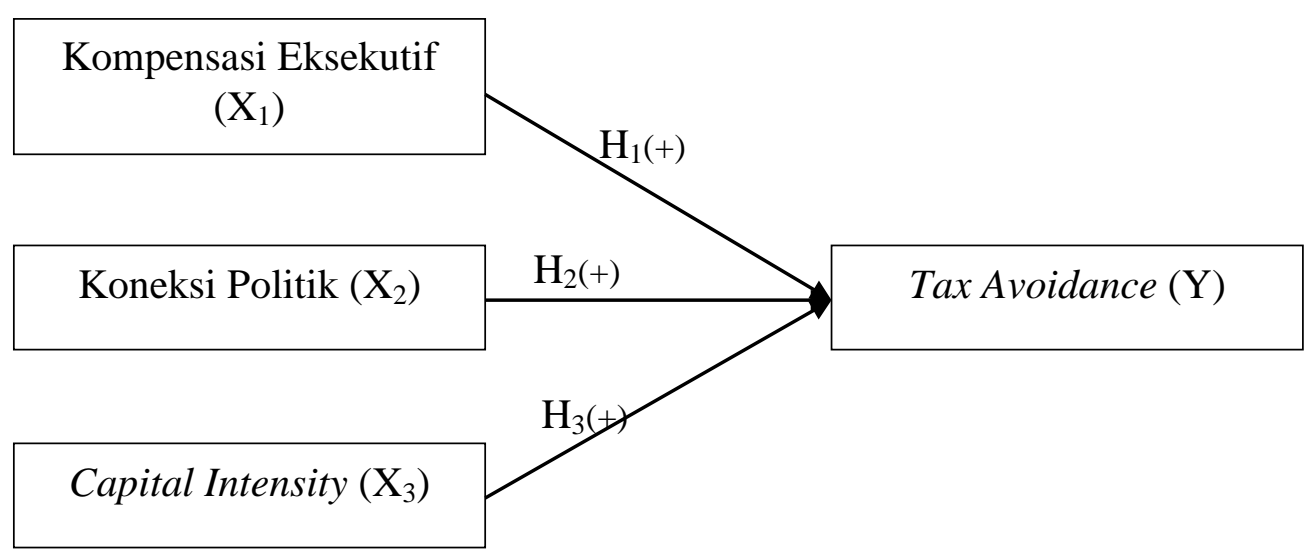

\section{Gambar 1. Desain Penelitian}

Penelitian ini dilakukan di Bursa Efek Indonesia yang menyediakan informasi laporan keuangan perusahaan dengan lengkap. Obyek dari penelitian ini Kompensasi Eksekutif $\left(\mathrm{X}_{1}\right)$, Koneksi Politik $\left(\mathrm{X}_{2}\right)$, Capital Intensity $\left(\mathrm{X}_{3}\right)$ dan Tax Avoidance (Y).Perusahaan yang diteliti adalah perusahaan property, real estate, dankonstruksi bangunan yang terdaftar di Bursa Efek Indonesia periode 2014-2016.

Variabel terikat dalam penelitian ini adalah tax avoidance.Lim (2011) mendefinisikan tax avoidance sebagai pemanfaatan ketentuan perpajakan secara legal untuk melakukan penghematan pajak dengan meminimalkan kewajiban pajak. Tax avoidance dapat diukur dengan effective tax rate (ETR). Penelitian ini sejalan dengan 
ISSN: 2302-8556

E-Jurnal Akuntansi Universitas Udayana

Vol.25.2.November (2018): 1481-1505

peneliti terdahulu Hanlon dan Heinztman (2010) menggunakan proksi ETR untuk mengukur tax avoidance. Rumus yang digunakan adalah sebagai berikut:

$$
\mathrm{ETR}=\frac{\text { Beban pajak }}{\text { Laba sebelum pajak }}
$$

Variabel bebas dalam penelitian ini adalah kompensasi eksekutif, koneksi politik, dan capital intensity. Proksi yang digunakan dalam mengukur kompensasi eksekutif adalah logaritma natural dari total kompensasi yang diterima dewan direksi, komisaris, maupun manajeman kunci selama satu tahun. Penelitian ini sejalan dengan penelitian terdahulu Armstrong, et al. (2015) menggunakan proksi logaritma natural total kompensasi setahun.

Kompensasi Eksekutif = Ln (Total Kompensasi)

Koneksi politik suatu perusahaan diukur menggunakan variabel dummy, dengan memberikan nilai 1 untuk perusahaan yang salah satu pemegang sahamnya adalah pemerintah (BUMN) dan 0 jika tidak (Mulyani dkk, 2014).

Capital Intensity adalah besarnya total modal yang tertanam dalam investasi berupa aset tetap perusahaan. Peneliti terdahulu Rodriguez dan Arias (2012), serta Ardyansah (2014) menyatakan bahwa capital intensity ini diukur dengan menggunakan rumus capital intensity ratio yang dirumuskan sebagai berikut:

$$
\mathrm{CIR}=\frac{\text { Total Aset Tetap }}{\text { Total Aset }}
$$

Populasi penelitian ini adalah seluruh perusahaan property, real estate, dankonstruksi bangunan yang terdaftar di Bursa Efek Indonesia BEI periode 20142016 yang berjumlah 51 perusahaan. Sampel penelitian ini diambil dengan 
menggunakan metode nonprobability sampling dengan menggunakan teknik purposive sampling.

Data yang digunakan dalam penelitian ini data kuantitatif yaitu laporan keuangan perusahaan property, real estate, dan konstruksi bangunan periode 20142016 yang terdaftar di Bursa Efek Indonesia dan data kuallitatif yaitu nama perusahaan property, real estate, dan konstruksi bangunan yang terdaftar di Bursa Efek Indonesia tahun 2014-2016. Sumber data yang digunakan bersumber dari data sekunder berupa laporan keuangan tahunan perusahaan property, real estate, dankonstruksi bangunan yang terdaftar di BEI tahun 2014-2016.

Dalam pengumpulan data metode yang digunakan adalah observasi non partisipan. Teknik analisis yang digunakan dalam penelitian ini adalah regresi linier berganda menggunakan rumus sebagai berikut:

$$
\mathrm{Y}=\alpha+\beta_{1} \mathrm{X}_{1}+\beta_{2} \mathrm{X}_{2}+\beta_{3} \mathrm{X}_{3}+\mathrm{e}
$$

Keterangan:

$$
\begin{array}{ll}
\mathrm{Y} & =\text { tax avoidance } \\
\alpha & =\text { konstanta } \\
\mathrm{X}_{1} & =\text { kompensasi eksekutif } \\
\mathrm{X}_{2} & =\text { koneksi politik } \\
\mathrm{X}_{3} & =\text { capital intensity } \\
\beta & =\text { koefisien regresi } \\
\mathrm{e} & =\text { error }
\end{array}
$$

\section{HASIL DAN PEMBAHASAN}

Adapun kriteria yang digunakan untuk seleksi sampel dalam penelitian ini adalah sebaga berikut: 
ISSN: 2302-8556

E-Jurnal Akuntansi Universitas Udayana

Vol.25.2.November (2018): 1481-1505

Tabel 2.

Proses Seleksi Sampel

\begin{tabular}{lc}
\hline \multicolumn{1}{c}{ Kriteria } & Jumlah \\
\hline Perusahaan property, real estate, dan konstruksi bangunan yang terdaftar & $\mathbf{5 1}$ \\
di Bursa Efek Indonesia secara berturut-turut selama periode 2014-2016. & \\
Perusahaan tidak menerbitkan laporan keuangan dan laporan tahunan yang & (2) \\
lengkap selama periode 2014-2016 & \\
$\begin{array}{l}\text { Perusahaan yang tidak memiliki data lengkap sesuai dengan keperluan } \\
\text { penelitian }\end{array}$ & (16) \\
Perusahaan mengalami kerugian selama periode 2014-2016. & (9) \\
\hline Jumlah Sampel Perusahaan (24 perusahaan x 3 tahun) & 72 \\
Data Outlier (12 perusahaan x 3 tahun) & (36) \\
\hline
\end{tabular}

Sumber: Data diolah, 2018

Analisis statistik desktiptif merupakan gambaran atau deskripsi data yang dilihat dari nilai maksimum, nilai minimum, nilai rata-rata (mean), dan standar deviasi.Hasil statistik deskriptif masing-masing variabel dalam penelitian ini dapat dlihat pada Tabel 3 .

Tabel 3.

Hasil Uji Statistik Deskriptif

\begin{tabular}{lccccc}
\hline \multicolumn{1}{c}{ Variabel } & N & Min. & Max. & Mean & Std. Deviasi \\
\hline KE $\left(\mathrm{X}_{1}\right)$ & 36 & 21,8051 & 25,2271 & 23,433717 & 0,9718530 \\
KP $\left(\mathrm{X}_{2}\right)$ & 36 & 0,00 & 1,00 & 0,1667 & 0,37796 \\
CI $\left(\mathrm{X}_{3}\right)$ & 36 & 0,0024 & 0,4871 & 0.065258 & 0,1170344 \\
ETR $(\mathrm{Y})$ & 36 & 0,0002 & 0,0183 & 0,007392 & 0,0055855 \\
\hline
\end{tabular}

Sumber: Data diolah, 2018

Tabel 3 menjunjukkan tax avoidance diproksikan menggunakan ETR pada perusahaan property, real estate, dan konstruksi bangunan yang terdaftar di BEI tahun 2014-2016 rata-rata sebesar 0,007392 dengan standar deviasi sebesar 
0,0055855. Perusahaan dengan nilai ETR terendah adalah Metropolitan Kentjana Tbksebesar 0,0002 pada tahun 2014. Perusahaan yang memiliki nilai ETR tertinggi adalah Lippo Cikarang Tbk sebesar 0,0183 pada tahun 2016.

Variabel bebas KE memiliki nilai rata-rata sebesar 23,433717 dengan standar deviasi sebesar 0,9718530. Perusahaan dengan nilai KE terendah adalah Pembangunan Perumahan (Persero) Tbk sebesar 21,8051 pada tahun 2014. Perusahaan yang memiliki nilai KE tertinggi adalah Intiland Development Tbk sebesar 25,2271 pada tahun 2016 .

Variabel bebas KP mempunyai nilai rata-rata sebesar 0,1667 dengan standar deviasi sebesar 0,37796. Nilai rata-rata sebesar 0,1667 menunjukkan bahwa rata-rata perusahaan yang mempunyai koneksi politik sebesar 16,67 persen dari total keseluruhan sampel. Diantara 36 sampel penelitian, terdapat 6 perusahaan yang dimiliki oleh pemerintah dan 30 perusahaan tidak dimiliki oleh pemerintah.

Variabel bebas CI mempunyai nilai rata-rata sebesar 0,065258 dengan standar deviasi sebesar 0,1170344. Perusahaan yang mempunyai nilai CI terendah ialah Goa Makkasar Tourism Development Tbk sebesar 0,0024 pada tahun 2016. Perusahaan yang mempunyai nilai CI tertinggi ialah Metropolitan Kentjana Tbk sebesar 0,4871 pada tahun 2014 .

Uji model regresi harus dilakukan dengan pengujian asumsi klasik pada model regresi yang akan digunakan. Uji asumsi klasik dalam penelitian ini meliputi uji normalitas, multikololinearitas, heteroskedastisitas danautokorelasi.Hasil uji asumsi klasik disajikan pada Tabel 4 berikut. 
ISSN: 2302-8556

E-Jurnal Akuntansi Universitas Udayana

Vol.25.2.November (2018): 1481-1505

Tabel 4.

Uji Asumsi Klasik

\begin{tabular}{|c|c|c|c|c|c|}
\hline \multirow{2}{*}{$\begin{array}{c}\text { Parameter yang } \\
\text { Diuji }\end{array}$} & \multirow{2}{*}{$\begin{array}{c}\text { Uji } \\
\text { Nomalitas } \\
\begin{array}{c}\text { Asymp. Sig. } \\
\text { (2-tailed) }\end{array} \\
\end{array}$} & \multicolumn{2}{|c|}{ Uji Multikolonieritas } & \multirow{2}{*}{$\begin{array}{c}\text { Uji Heteroskedastisitas } \\
\text { Sig. }\end{array}$} & \multirow{2}{*}{$\begin{array}{c}\begin{array}{c}\text { Uji } \\
\text { Autokorelas }\end{array} \\
\text { DW }\end{array}$} \\
\hline & & Tolerance & VIF & & \\
\hline $\begin{array}{l}\text { Unstandardized } \\
\text { Residual }\end{array}$ & 0,200 & & & & \\
\hline $\mathrm{KE}\left(\mathrm{X}_{1}\right)$ & & 0,797 & 1,225 & 0,375 & \\
\hline $\mathrm{KP}\left(\mathrm{X}_{2}\right)$ & & 0,828 & 1,208 & 0,355 & \\
\hline $\mathrm{CI}\left(\mathrm{X}_{3}\right)$ & & 0,923 & 1,083 & 0,065 & \\
\hline Durbin-Watson & & & & & 1,823 \\
\hline
\end{tabular}

Sumber: Data diolah, 2018

Nilai signifikansi dari hasil uji normalitas persamaan model penelitian ini ialah sebesar 0,200 . Nilai $0,200>0,05$ berarti model regresi pada penelitian ini berdistribusi normal.Berdasarkan uji multikolonearitas diperoleh nilai tolerance dari setiap variabel lebih besar dari 0,10 dan VIF lebih kecil dari 10, hal ini menunjukkan bahwa tidak terjadi multikolinieritas antara kedua variabel bebas dan menggambarkan asumsi multikolinieritas terpenuhi. Tabel 4 menunjukkan nilai DW sebesar 1,832. Hasil uji autokorelasi adalah $\mathrm{d}_{U}<\mathrm{DW}<4-\mathrm{d}_{\mathrm{U}}$ yaitu $1,6539<1,832<2,3461$. Simpulan yang didapat dari hasil autokorelasi tersebut adalah model regresi yang digunakan bebas dari autokorelasi. Hasil analisis regresi linier bergandadisajikan pada Tabel 5 berikut.

\section{Tabel 5.}




\section{Uji Regresi Linier Berganda}

\begin{tabular}{|c|c|c|c|c|c|c|}
\hline \multirow{2}{*}{ Model } & \multicolumn{2}{|c|}{$\begin{array}{c}\text { Unstandardized } \\
\text { Coefficients }\end{array}$} & \multirow{2}{*}{$\begin{array}{c}\begin{array}{c}\text { Standardized } \\
\text { Coefficients }\end{array} \\
\text { Beta }\end{array}$} & \multirow{2}{*}{$\mathbf{T}$} & \multirow{2}{*}{ Sig. } & \multirow{2}{*}{$\begin{array}{l}\text { Hasil Uji } \\
\text { Hipotesi }\end{array}$} \\
\hline & $\boldsymbol{B}$ & $\begin{array}{c}\text { Std. } \\
\text { Error }\end{array}$ & & & & \\
\hline (Constant) & 0,059 & 0,023 & & 2,551 & 0,016 & \\
\hline $\operatorname{KE}\left(\mathrm{X}_{1}\right)$ & $-0,002$ & 0,001 & $-0,376$ & $-2,187$ & 0,036 & $\mathrm{H}_{1}$ Ditolak \\
\hline $\mathrm{KP}\left(\mathrm{X}_{2}\right)$ & $-0,002$ & 0,002 & $-0,140$ & $-0,830$ & 0,413 & $\mathrm{H}_{2}$ Ditolak \\
\hline $\mathrm{CI}\left(\mathrm{X}_{3}\right)$ & $-0,013$ & 0,008 & $-0,272$ & $-1,702$ & 0,098 & $\mathrm{H}_{3}$ Ditolak \\
\hline $\mathrm{R}$ & 0,495 & & & & & \\
\hline$R$ Square & 0,245 & & & & & \\
\hline $\begin{array}{l}\text { Adjusted } R \\
\text { Square }\end{array}$ & 0,174 & & & & & \\
\hline F Hitung & 3,466 & & & & & \\
\hline Sig. F & 0,028 & & & & & \\
\hline
\end{tabular}

Berdasarkan Tabel 5 persamaan regresi yang digunakan dalam penelitian ini dapat ditulis sebagai berikut:

$$
\mathrm{Y}=0,059-0,002 \mathrm{X}_{1}-0,002 \mathrm{X}_{2}-0,013 \mathrm{X}_{3}+\varepsilon
$$

Nilai konstan sebesar 0,059 menunjukkan jika kompensasi eksekutif $\left(\mathrm{X}_{1}\right)$, koneksi politik $\left(\mathrm{X}_{2}\right)$, dan capital intensity $\left(\mathrm{X}_{3}\right)$ tidak ada atau bernilai nol, maka besarnya tingkat tax avoidance (Y) perusahaan adalah sebesar 0,059 satuan.Nilai $\beta_{1}$ sebesar -0,002 menunjukkan bahwa jika kompensasi eksekutif $\left(\mathrm{X}_{1}\right)$ mengalami kenaikan sebesar satu satuan maka akan terjadi penurunan tax avoidance (Y) sebesar 0,002 dengan asumsi variabel independen lainnya konstan.Nilai $\beta_{2}$ sebesar $-0,002$ menunjukkan bahwa jika koneksi politik $\left(\mathrm{X}_{2}\right)$ mengalami kenaikan sebesar satu satuan maka akan terjadi penurunan tax avoidance $(\mathrm{Y})$ sebesar 0,002 dengan asumsi variabel independen lainnya konstan. Nilai $\beta_{3}$ sebesar $-0,013$ menunjukkan bahwa jika capital intensity $\left(\mathrm{X}_{3}\right)$ mengalami kenaikan sebesar satu satuan maka akan terjadi 
ISSN: 2302-8556

E-Jurnal Akuntansi Universitas Udayana

Vol.25.2.November (2018): 1481-1505

penurunan tax avoidance (Y) sebesar 0,013 dengan asumsi variabel independen lainnya konstan.

Tabel5 menunjukkan bahwa kompensasi eksekutif memiliki koefisien regresi sebesar -0,002 dengan nilai signifikansi sebesar 0,036 lebih kecil dari tingkat signifikansi 0,05. Hasil tersebut menunjukkan kompensasi eksekutif berpengaruh negatif dan signifikan pada tax avoidance. Artinya semakin tinggi kompensasi eksekutif yang diberikan perusahaan, maka kinerja eksekutif akan semakin meningkat dan tidak akan melakukan tindakan tax avoidance karena itu akan menjadi tanggungjawabnya.

Hasil penelitian ini mengkorfimasi teori agensi yang menjelaskan bahwa principal memberikan tanggung jawab untuk mengelola perusahaan kepada pihak manajemen, sehingga manajemen wajib untuk mempertanggungjawabkannya kepada principal. Eksekutif bertanggungjawab atas segala keputusan dari kebijakan yang ditetapkan oleh perusahaan. Tindakan tax avoidance yang dilakukan perusahaan akan membuat citra perusahaan menjadi buruk. Eksekutif sebagai pembuat kebijakan tidak akan melakukan tindakan tax avoidance agar citra perusahaan tidak menjadi buruk.

Hasil penelitian ini juga mengkonfirmasi theory of planned behavior, yaitu normative beliefs yang menjelaskan keyakinan individu tentang harapan normatif orang lain yang menjadi rujukannya dan motivasi untuk memenuhi harapan tersebut. Kinerja perusahaan yang baik dan tidak melakukan tindakan tax avoidance akan membuat citra perusahaan menjadi baik, sehingga kepercayaan masyarakat akan semakin meningkat dan menyebabkan perusahaan mendapatkan keuntungan. 
Hasil yang diperoleh tidak sejalan dengan penelitian yang dilakukan Minnick dan Noga (2010), Rego dan Wilson (2012), serta Hanafi dan Hartono (2014) menemukan kompensasi eksekutif berpengaruh positif pada penghindaran pajak. Penelitian ini berpengaruh juga tidak sejalan dengan penelitian yang dilakukan oleh Irawan dan Farahmita (2012), Puspita dan Harto (2014), Dewi dan Maria (2015) serta Setyowati (2016) menyatakan bahwa kompensasi eksekutif tidak berpengaruh pada penghindaran pajak, sedangkan penelitian ini berpengaruh signifikan.

Tabel 5 menunjukkan bahwa koneksi politik memiliki koefisien regresi sebesar -0,002 dan nilai signifikansi sebesar 0,413 lebih besar dari tingkat signifikansi 0,05 . Hasil tersebut menunjukkan koneksi politik berpengaruh negatif dan tidak signifikan tax avoidance. Artinya semakin tinggi koneksi politik yang dimiliki oleh perusahaan tidak akan mempengaruhi aktivitas tax avoidance perusahaan.

Perusahaan bisa mendapatkan manfaat dari kedekatannya dengan pemerintah, namun perusahaan juga harus memikirkan dampak jangka panjang yang akan ditimbulkan. Dampak jangka panjang dari buruknya citra perusahaan adalah menurunnya kepercayaan masyarakat dan perusahaan akan mengalami kerugian. Masyarakat memutuskan untuk berinvestasi maupun menggunakan produk dari suatu perusahaan dengan melihat citra dari suatu perusahaan.

Hasil penelitian ini mengkorfimasi teori agensi yang menjelaskan bahwa principal memberikan tanggung jawab untuk mengelola perusahaan kepada pihak manajemen, sehingga manajemen wajib untuk mempertanggungjawabkannya kepada 
ISSN: 2302-8556

E-Jurnal Akuntansi Universitas Udayana

Vol.25.2.November (2018): 1481-1505

principal. Perusahaan yang memanfaatkan kedekatannya dengan pemerintah dengan melakukan tax avoidance akan memiliki citra buruk dimata masyarakat. Eksekutif sebagai pembuat kebijakan tidak akan memanfaatkan kedekatannya dengan pemerintah dengan melakukan tindakan tax avoidance agar citra perusahaan tidak menjadi buruk.

Hasil dari penelitian ini juga mengkonfirmasi theory of planned behavior, yaitu normative beliefs yang menjelaskan keyakinan individu tentang harapan normatif orang lain yang menjadi rujukannya dan motivasi untuk memenuhi harapan tersebut. Perusahaan yang tidak memanfaatkan kedekatannya dengan pemerintah dan tidak melakukan tindakan tax avoidance akan membuat citra perusahaan menjadi baik, sehingga kepercayaan masyarakat akan semakin meningkat dan menyebabkan perusahaan mendapatkan keuntungan. Hasil penelitian ini sesuai dengan penelitian Dharma dan Ardiana (2016), serta Lestari dan Asri (2017) yang menemukan bukti empiris bahwa koneksi politik tidak memiliki pengaruh pada tax avoidance.

Tabel 5 menunjukkan bahwa capital intensity memiliki koefisien regresi sebesar -0,013 dan nilai signifikansi sebesar 0,098 lebih besar dari tingkat signifikansi 0,05. Hasil tersebut menunjukkan bahwa capital intensity berpengaruh negatif dan tidak signifikan pada tax avoidance. Artinya semakin tinggi capital intensity yang dimiliki oleh perusahaan tidak akan mempengaruhi aktivitas penghindaran pajakperusahaan.

Aset tetap yang tinggi dimiliki oleh perusahan memang digunakan untuk kepentingan operasional dan investasi, sehingga proporsi aset tetap yang tinggi tidak 
akan memengaruhi tingkat penghindaran pajak perusahaan. Hasil penelitian ini mengkorfimasi teori agensi yang menjelaskan bahwa principal memberikan tanggung jawab untuk mengelola perusahaan kepada pihak manajemen, sehingga manajemen wajib untuk mempertanggungjawabkannya kepada principal.Tingginya asset tetap yang dimiliki perusahaan memang digunakan untuk kepentingan operasional dan investasi perusahaan bukan untuk penghindaran pajak. Tindakan tax avoidance yang dilakukan perusahaan akan membuat citra perusahaan menjadi buruk. Eksekutif sebagai pembuat kebijakan tidak akan melakukan tindakan tax avoidance agar citra perusahaan tidak menjadi buruk.

Hasil penelitian ini juga mengkonfirmasi theory of planned behavior, yaitu normative beliefs yang menjelaskan keyakinan individu tentang harapan normatif orang lain yang menjadi rujukannya dan motivasi untuk memenuhi harapan tersebut. Aset tetap yang dimiliki perusahaan memang digunakan untuk kepentingan operasional perusahaan dan perusahaan yang tidak melakukan tindakan tax avoidance mengakibatkan citra perusahaan menjadi baik, sehingga kepercayaan masyarakat akan semakin meningkat dan menyebabkan perusahaan mendapatkan keuntungan.Hasil penelitian ini sesuai dengan penelitian Chiou et al. (2012), Ardyansyah (2014), serta Cahyadi dan Lely (2016) menemukan capital intensity tidak berpengaruh pada tax avoidance.

\section{SIMPULAN}

Simpulan yang dapat ditarik dari hasil penelitian yang telah diuraikan, yaitukompensasi eksekutif berpengaruh negatif dan signifikan pada tax avoidance, 
ISSN: 2302-8556

E-Jurnal Akuntansi Universitas Udayana

Vol.25.2.November (2018): 1481-1505

koneksi politik berpengaruh negatif dan tidak signifikan pada tax avoidance, dan capital intensity berpengaruh negatif dan tidak signifikan pada tax avoidance. Saran yang diberikan pada perusahaan disarankan lebih memerhatikan keputusan yang akan dilakukan serta risiko dari keputusan yang dibuat apakahsudah sesuaidengan undangundang perpajakan yang berlaku. Kompensasi eksekutif memiliki pengaruh yang cukup dominan pada tingkat tax avoidance suatu perusahaan, oleh karena itu investor yang ingin berinvestasi ke suatu perusahaan sebaiknya melihat besarnya kompensasi eksekutif yang diberikan perusahaan untuk mengetahui apakah perusahaan melakukan tindakan tax avoidance atau tidak.

\section{REFERENSI}

Adhikari Ajay, Chek Derashid and Hao Zhang. 2006. Public Policy, Political Connections and Effective Tax Rates: Longitudinal Evidence from Malaysia. Journal of Accounting and Public Policy, 25, pp: 574-995.

Ajzen, Icek. 1991. The Theory of Planned Behavior. Journal of Organizational Behavior and Human Decision Process, 50, pp: 179-211

Anthony, R. N., \& Govindarajan, V. 2009.Management Control System.Jakarta: Salemba Empat.

Ardyansyah, Dannis. 2014. Pengaruh Size, Leverage, Profitability, Capital Intensity Ratio, dan Komisaris Independen padaEffective Tax Rate (ETR) (Studi Empiris pada Perusahaan Property dan Real Estate yang tercatat di BEI Periode 2010-2012). Jurnal Akuntansi Universitas Diponogoro

Armstrong, C.S., J.L. Blouin, and D.F. Larcker. 2015. Corporate Governance, Incentive, and Tax Avoidance. Journal of Accounting and Economics, 60 (1), pp: $1-17$.

Arianti, Fiki. 2016. https://www.google.co.id/amp/s/m. liputan6.com/amp2626083 /membongkar-strategi-penghindaran-pajak-google-di-dunia. (Diakses 10 Februari 2018) 
Arnold, Brain J and Michael J.McIntyre,. 2002. International Tax Primer.New York: Kluwer Law International

Butje, Stella dan Elisa Tjondro.2014. Pengaruh Karakteristik Eksekutif dan Koneksi Politik PadaTax Avoidance.Tax and Accounting ReviewUniversitas Kristen Petra, 4 (2).

Cahyadi Putra,I Gst Ln Ngr Dwi dan Ni Ketut Lely Aryani Merkusiwati. 2016. Pengaruh Komisaris Independen, Leverage, Size dan Capital Intensity Ratio pada Tax Avoidance. E-Jurnal Akuntansi Universitas Udayana, 17 (2), hal.690-714.

Chiou YC, Hsieh YC, Lin W. 2012. Determinants of Effect Tax Rates For Firm Listed On China`s Stock Markets: Panel Models With Two-Sided Censors. International Trade and Academic Research Conference (ITARC).7-8th November 2012

Darmadi, I. H., dan Zulaikha.2013. Analisis Faktor yang Mempengaruhi Manajemen Pajak dengan Indikator Tarif Pajak Efektif (Studi Empiris pada Perusahaan Manufaktur yang Terdaftar di Bursa Efek Indonesia pada Tahun 20112012).Diponegoro Journal of Accounting, 4 (2), hal.1-12.

Desai, M. A., \& Dharmapala, D. 2006.Corporate Tax Avoidance and High-Powered Incentives.Journal of Financial Economics, 79 (1), pp: 145-179.

Dewi, Gusti Ayu Pradnyanita dan Maria M Ratna.2015. Pengaruh Insentif Eksekutif, Corporate Risk dan Corporate Governance pada Tax Avoidance.E-Jurnal Akuntansi Universitas Udayana, 13 (1), hal.50-67.

Dharma, I Made Surya dan Putu Agus Ardiana. 2016. Pengaruh Leverage, Intensitas Aset Tetap, dan Koneksi Politik padaTax Avoidance. E-Jurnal Akuntansi Universitas Udayana, 15 (1), hal.584-613.

Dharma, Nyoman Budhi Setya dan Naniek Noviari.2017.Pengaruh Corporate Social Responsibilitydan Capital IntensitypadaTax Avoidance.E-Jurnal Akuntansi Universitas Udayana, 18 (1), hal.529-556.

Dwilopa, Dio Erlangga. 2016. Pengaruh Corporate Social Responsibility, CapitalIntensity, dan Perencanaan Pajak pada Penghindaran Pajak. Naskah Publikasi.

Faccio, Mara. 2006. Politically Connected Firms. The American Economic Review, 96 (1), pp: 369-386. 
ISSN: 2302-8556

E-Jurnal Akuntansi Universitas Udayana

Vol.25.2.November (2018): 1481-1505

Ferdiawan, Yopi dan Amrie Firmansyah. 2017. Pengaruh Political Connection, Foreign Activity, dan Real Earnings Management padaTax Avoidance. Jurnal Riset Akuntansi dan Keuangan Politeknik Keuangan Negara STAN.

Hanafi, U. Dan Hartono, P. 2014. Analisis Pengaruh Kompensasi Eksekutif, Kepemilikan Saham Eksekutif, dan Preferensi Risiko Eksekutif pada Penghindaran Pajak Perusahaan. Diponogoro Journal of Accounting, 3 (2), hal.1162-1172.

Hanlon, M. and S. Heitzman. 2010. A Review Of Tax Research. Journal of Accounting and Economics, 50, pp: 127-178.

Irawan, H.P. dan A. Farahmita.2012. Pengaruh Kompensasi Manajemen dan Corporate GovernancepadaTax Avoidance.Skripsi.Fakultas Ekonomi Universitas Indonesia.

Jensen, Michael C and William H. Meckling. 1976. Theory of the Firm: Managerial Behavior. Agency Cost and Ownership Structure. Journal of Financial Economic, 3 (4).

Laporan Kinerja DJP. 2016. https://www.pajak.go.id/sites/default/files/laporankinerja-DJP.(Diunduh tanggal 18 Februari 2018).

Lestari, Gusti Ayu Widya dan I.G.A.M Asri Dwija Putri. 2017. Pengaruh Corporate Governance, Koneksi Politik, dan Leverage pada Penghindaran Pajak. EJurnal Akuntansi Universitas Udayana, 18 (3), hal.2028-2054.

Leuz, C., and F. Oberholzer-Gee. 2006. Political Relationships, Global Financing, and Corporate Transparency: Evidence from China. The European Journal of Finance, 20, pp: 1-19.

Lim.Y.D. 2011. TaxAvoidance, Cost of Debt and Shareholder Activism: Evidence From Korea. Journal of Banking \& Finance,35, pp: 456-470.

Minnick, K. and T. Noga. 2010. Do Corporate Governance Characteristics Influence Tax Management. Journal of Corporate Finance, 16, pp: 703-718.

Mulyani, S., Darmito, dan Endang, M. W. 2014. Pengaruh Karakteristik Perusahaan, Koneksi Politik, dan Reformasi Perpajakan Pada Penghindaran Pajak (Studi pada Perusahaan Manufaktur yang Terdaftar di BEI tahun 2008-2012). Jurnal Mahasiswa Perpajakan Universitas Brawijaya, 1 (2), hal.1-9. 
Muzakki, Muadz Rizki dan Darsono. 2015. Pengaruh Corporate Social Responsibility dan Capital Intensity pada Penghindaran Pajak. Diponegoro Journal of Accounting, 4 (3), hal.1-8.

Noor, Md Rohaya et al. 2010. Corporate Tax Planning: A Study on Corporate Effective Tax Rates of Malaysian Listed Company. International Journal of TradeEconomics and Finannce, 1 (2).

Purwoto, Lukas. 2011. Pengaruh Koneksi Politik, Kepemilikan Pemerintah dan Keburaman Laporan Keuangan pada Kesingkronan dan Risiko Crash Harga Saham. Disertasi Program Doktor Ilmu Ekonomi Manajemen Universitas Gajah Mada

Puspita, Slivia Ratih dan Harto, Puji. 2014. Pengaruh Tata Kelola Perusahaan Pada Penghindaran Pajak. Diponegoro Journal Of Accounting, 3 (2), hal. 1-13.

Rego, S.O. dan R. Wilson. 2012. Equity Risk Incentives and Corporate Tax Aggressiveness. Journal of Accounting Research, 50 (3), pp: 775-810.

Richardson, Grant and R. Laris. 2007. Determinants of Variability In Corporate Effective Tax Rates and Tax Reform: Evidence From Australia. Journal of Accounting and Public Policy, 26, pp: 689-704.

Rodriguez, E. F. and Arias, A.M. 2012. Do Business Characteristics Determine an Effective Tax Rate.Journal of Chinese Economy, 45 (6).

Setyowati. 2016. Pengaruh Kompensasi Eksekutif, Kepemilikan Saham Eksekutif, Preferensi Risiko Eksekutif dan KarakteristikEksekutif Pada Penghindaran Pajak Perusahaan.Naskah Publikasi Jurusan Akuntansi Fakultas Ekonomi dan Bisnis Universitas Muhammadiyah Yogyakarta

Sumarsan, Thomas. 2010. Perpajakan Indonesia:Pedoman Perpajakan yang Lengkap Berdasarkan Undang-Undang Terbaru. Jakarta : Indeks.

Surbakti, Theresa Adelina Victoria.2012. Pengaruh Karakteristik Perusahaan dan Reformasi Perpajakan Pada Penghindaran Pajak di Perusahaan Industri Manufaktur yang Terdaftar di Bursa Efek Indonesia Tahun 2008-2010.Skripsi Jurusan Akuntansi Fakultas Ekonomi Universitas Indonesia, Jakarta.

Tehupuring, Ronald dan Ellia Rossa. 2016. Pengaruh Koneksi Politik dan Kualitas Audit pada Praktik Penghindaran Pajak di Lembaga Property dan Real Estate 
ISSN: 2302-8556

E-Jurnal Akuntansi Universitas Udayana

Vol.25.2.November (2018): 1481-1505

yang Terdaftar di Pasar Modal Indonesia Periode 2012-2014. Prosiding Seminar Nasional INDOCOMPAC.

Utari, Ni Kadek Yuliani dan Ni Luh Supadmi. 2017. Pengaruh Corporate Governance, Profitabilitas, dan Koneksi Politik pada Tax Avoidance. E-Jurnal Akuntansi Universitas Udayana, 18 (3), hal. 2202-2230.

Wiguna, I Putu Putra dan I Ketut Jati. 2017. Pengaruh Corporate Social Responsibility, Preferensi Risiko Eksekutif, dan Capital Intensity pada Penghindaran Pajak. E-Jurnal Akuntansi Universitas Udayana, 21 (1), hal.418-446. 